\title{
Effect of Nitrogen Sources on Microbial Biomass Nitrogen under Different Soil Types
}

\author{
Haytham M. El-Sharkawi \\ Central Laboratory for Agricultural Climate (CLAC), Agricultural Research Center (ARC), Dokki, Giza 12411, Egypt \\ Correspondence should be addressed to Haytham M. El-Sharkawi, haythame@gmail.com
}

Received 7 December 2011; Accepted 10 January 2012

Academic Editor: S. Yamulki

Copyright ( 2012 Haytham M. El-Sharkawi. This is an open access article distributed under the Creative Commons Attribution License, which permits unrestricted use, distribution, and reproduction in any medium, provided the original work is properly cited.

\begin{abstract}
Knowledge to increase the microbial biomass nitrogen $(\mathrm{MBN})$ as a bulk of free-living microbes in paddy soil is limited. The potential benefit of these microorganisms was evaluated, in this study, under different nitrogen sources and two paddy soils. The results revealed that pots treated with organic matter recorded the maximum value of the total $\mathrm{N}$ uptake and MBN, followed by the Urea treated pots. Pots amended with sludge exhibited a higher microbial $\mathrm{N}$ forming ability than those amended with straw compost under both soils. But ammonium concentration in soil increased with straw compost application. Under fresh soil treatment, microbial $\mathrm{N}$ uptake rate and proportion of plant nitrogen derived from microbial nitrogen sources $\left(P_{\text {fix }}\right)$ were higher than autoclaved soil. A positive correlation was found between the $P_{\text {fix }}$ and the total $\mathrm{N}$ in rice shoot in both soils. Finally, we can say that MBN was governed not only by the soil nitrogen content but also by the type of the nitrogen source. The addition of sludge to fresh soil increased total MBN and consequently could be indirectly beneficial to rice production especially in poor soils. Thus, soil microbes contribute to plant growth by serving the available nitrogen during the season.
\end{abstract}

\section{Introduction}

Maximizing MBN in the soil offers a potential approach to improving the production efficiency of soil. Recycling of microbial $\mathrm{N}$ in the soil occurs as a result of degradation of microbial biomass [1-3]. Billions of organisms inhabit the upper layers of the soil, where they break down dead organic matter, releasing the nutrients necessary for plant growth. The microorganisms include bacteria, actinomycetes, algae, and fungi. Macroorganisms include earthworms and arthropods such as insects, mites, and millipedes. Each group plays a role in the soil ecosystem and can assist the organic farmer in producing a healthy crop. Microorganisms can be grouped according to their function: free-living decomposers convert organic matter into nutrients for plants, and other microorganisms, rhizosphere organisms, are symbiotically associated with the plant roots and free-living nitrogen fixers [4-8]. Plant roots leak or exude a large number of organic substances and continually slough off root caps into the soil. These materials are food for the many microorganisms living in a zone of intense microbial activity near the roots called the rhizosphere. Bacteria benefit most from the food supplied in the rhizosphere and may form a continuous film around the root. Other micro-organisms liberate nutrients from the clay and humus colloids (a colloid is a mass of fine particles) $[6,8]$.

There is great diversity in the metabolic types of freeliving microorganisms which are capable to extract the nitrogen from organic and soil substances and then release it (microbial nitrogen) to the soil pool as one of the available nitrogens for plant nutrition in soil. Soil nitrogen pool is naturally maintained through the microbial activity $[9,10]$. Sustainability of $\mathrm{N}$ cannot be considered in isolation; it must be considered holistically within the framework of system sustainability. With the current emphasis on the use of renewable resources for environmentally sustainable development, it is timely to assess the potential of microbial $\mathrm{N}$ to complement fertilizer inputs and to consider their contribution to rice plant under flooding condition. The capacity of soil micro-organisms under flooded rice condition should be improved to maintain or enhance rice production on the long term in a way that is economically viable and socially 
acceptable on the short term. Maintenance of adequate levels of soil organic matter is essential for a sustainable high production of crop [11]. Organic amendments contain useful macronutrients such as nitrogen, phosphorus, and potassium, as well as large amount of carbon, which serve as a substrate for the production of microbial biomass [12]. It appears that there are two ways in which organic matter is used for energy by soil micro-organisms, that is, directly through the use of some hemicellulose components [13-15] or indirectly through the use of products of organic decomposition [16-18]. The use of organic matter such as sludge and rice straw compost is of the major ways (along with crop rotation and green manure) used throughout history to maintain soil fertility [19]. Thus, intensive agriculture systems with high inorganic fertilizer inputs, however, limit the return of crop residues to the soil [20]. Maximizing nitrogen content in plant not only entails maximizing the application of organic matter or chemical fertilizer, but also requires that recovery of nitrogen is optimized [15]. Nitrogen transformations are occurring during breakdown of soil microorganisms which are influenced by residue management and soil physical and chemical properties [21]. With the aim of evaluating the potential use of microbial biomass nitrogen under different soil types, the objectives of this study were to (1) determine whether different nitrogen sources and soil types could increase the MBN which has been not evaluated and determined yet under paddy soils, (2) to evaluate the effect of different $\mathrm{N}$ sources on the relationship between the microbial $\mathrm{N}$ uptake by rice plant and the nitrogen mineralization determined by $\mathrm{NH}_{4}$ concentration increase.

\section{Materials and Methods}

2.1. Experimental Design and Treatment Structure. Pot experiments were conducted during summer seasons of 2007 and 2008 using two paddy soils (clay and silt loamy). Both soils were collected from the paddy fields located near Rice Research and Training Center, Sakha, and New Valley Governorate, Egypt, respectively. Selected characteristics of the experimental soil and organic matters are listed in Table 1. Both locations have been cultivated with rice several years ago. Experiments were carried out in a greenhouse. Nontransparent PVC cylinders $(h=35 \mathrm{~cm}, d=25 \mathrm{~cm})$ were filled with $4 \mathrm{~kg}$ of air-dried and sieved soil ( $2 \mathrm{~mm}$ mesh). Three nitrogen sources were applied: (i) sludge manure, (ii) rice straw compost which is made by mixing of the rice straw and cow manure, (iii) a basal dose of urea as control, and (iv) no $\mathrm{N}$ application. Both of the sludge and straw were sieved through a $2 \mathrm{~mm}$ sieve. There were a total of 16 treatments (i.e., (three nitrogen sources and a control) $\times$ (two soil conditions; autoclaved and fresh soil $\times$ two soil types)). The 64 pots (counting 16 treatments replicated 4 times) were arranged into a complete randomized block design within $12 \times 8$ arrays of rows of pots $40 \mathrm{~cm}$ apart. Soils of 32 pots were autoclaved separately after mixing with straw and sludge materials, and the other 32 pots were used as fresh soils which contained all microorganisms. soil microbes were killed by autoclaving in a Sterilmatic sterilizer
TABLE 1: Chemical and physical properties of soil and organic matter.

\begin{tabular}{lcccc}
\hline \multirow{2}{*}{ Parameter } & \multirow{2}{*}{ Clay* soil } & $\begin{array}{c}\text { Silt loam* } \\
\text { soil }\end{array}$ & \multicolumn{2}{c}{ Organic matter } \\
Sludge & Straw \\
\hline $\mathrm{pH}$ (solid/water) & 5.45 & 5.2 & 7.91 & 6.03 \\
Total C (\%) & 3.01 & 3.2 & 33.30 & 22.00 \\
Total N (\%) & 0.32 & 0.12 & 2.84 & 5.45 \\
C/N ratio & 9.38 & 26.6 & 11.9 & 4.00 \\
Total P (mg Kg & & & \\
Organic matter $(\%)$ & 500 & 250 & 4800 & 2600 \\
\hline
\end{tabular}

*(According to [22]).

(Market Forge Industries, Everett, MA) at $121^{\circ} \mathrm{C}$ for $30 \mathrm{~min}$ on two consecutive days. The application rate of nitrogen was applied based on $100 \mathrm{Kg} \mathrm{N} \mathrm{ha}^{-}$. Half of the chemical nitrogen (Urea) fertilizer was applied at 20 days after seeding, and the second half was applied at the maximum tillering stage. Phosphorus fertilizer was applied at the time of seeding $\left(36 \mathrm{Kg} \mathrm{Pha}^{-1}\right.$ as $\mathrm{Ca}\left(\mathrm{H}_{2} \mathrm{PO}_{4}\right)$ ). Eight rice (Oryza sativa L. var. Giza 177) seeds were planted per pot on 22 May 2007 and on 20 May 2008 and then thinned to four plants per pot at 10 days after seeding. After 15 days, the water level was raised to a height of about $2 \mathrm{~cm}$ above the soil, and it was maintained at that level thereafter until maximum tillering stage at the time of sampling.

2.2. Soil Analyses. At maximum tillering stage, soil ammonium $\left(\mathrm{NH}_{4}{ }^{+}-\mathrm{N}\right)$ content was determined in two fresh soil samples of each pot. Using the indophenol-blue method $[4,23]$, ammonium was determined after extraction with $2 \mathrm{M} \mathrm{KCl}$. The water content of samples was determined in order to express the results of $\mathrm{NH}_{4}-\mathrm{N}$ on oven-dry basis. Two samples were taken from the $0-15 \mathrm{~cm}$ depth to determine the amount of total soil $\mathrm{N}$ at maximum tillering stage. The soil samples were air-dried, ground and sieved using a $0.5 \mathrm{~mm}$ stainless sieve, and stored under laboratory condition until being analyzed. The total content of nitrogen and carbon in the soil and plant was determined using the Sumi-Graph CHN-21 analyzer at Tottori University Japan $[8,24]$.

2.3. Rice Plant Analyses. Two rice plants were harvested at maximum tillering (65 days from seeding) from each pot to determine the amount of $\mathrm{N}$ in rice shoot. The rice shoot was washed with tap water followed by distilled water and then oven dried at $70^{\circ} \mathrm{C}$. After determining the shoot dry weight (SDW), the plant samples were ground in a vibrating sample mill (Heiko T1-100, Heiko Seisakusho Ltd, Tokyo, Japan). The ground samples were analyzed for total $\mathrm{N}$ content by a CHN-21 analyzer as described previously. Nitrogen uptake in rice shoot was determined by multiplying the $\mathrm{N}$ concentration by shoot dry weight. The total amount of microbial $\mathrm{N}$ absorbed by rice plant was determined by $\mathrm{N}$ difference method at maximum tillering stage [8, 25-28]. Amount of microbial $\mathrm{N}$ was calculated from the difference between the extractable $\mathrm{N}$ from fresh soil and autoclaved soil samples under the same treatment as shown in the following 
TABLE 2: Ammonium concentration, nitrogen uptake, and SDW (combined of two years) of rice cv. Giza 177 as affected by nitrogen sources and microbial biomass.

\begin{tabular}{|c|c|c|c|c|c|c|c|c|}
\hline \multirow{2}{*}{ Treatments } & \multicolumn{4}{|c|}{ Clay soil } & \multicolumn{4}{|c|}{ Loamy soil } \\
\hline & $\begin{array}{c}\mathrm{TN} \text { in soil } \\
(\%)\end{array}$ & $\begin{array}{c}\mathrm{NH}_{4} \\
\left(\mathrm{mg} \mathrm{kg}^{-1}\right)\end{array}$ & $\begin{array}{l}\text { N uptake } \\
\left({\left.\mathrm{mg} p \mathrm{pot}^{-1}\right)}^{-1}\right.\end{array}$ & $\begin{array}{c}\text { SDW } \\
\left(\mathrm{g} \mathrm{pot}^{-1}\right)\end{array}$ & $\begin{array}{l}\mathrm{TN} \text { in soil } \\
(\%)\end{array}$ & $\begin{array}{c}\mathrm{NH}_{4} \\
\left(\mathrm{mg} \mathrm{kg}^{-1}\right)\end{array}$ & $\begin{array}{l}\text { N uptake } \\
\left(\mathrm{mg} \mathrm{pot}^{-1}\right)\end{array}$ & $\begin{array}{c}\text { SDW } \\
\left(\mathrm{g} \mathrm{pot}^{-1}\right)\end{array}$ \\
\hline \multicolumn{9}{|l|}{ Nitrogen sources } \\
\hline Zero N & 0.25 & 14.31 & 160 & 10.79 & 0.10 & 11.25 & 60 & 3.91 \\
\hline Urea & 0.41 & 21.44 & 430 & 21.83 & 0.19 & 15.45 & 110 & 9.43 \\
\hline Straw & 0.42 & 23.93 & 580 & 21.15 & 0.21 & 19.50 & 160 & 11.10 \\
\hline Sludge & 0.43 & 22.77 & 600 & 21.55 & 0.22 & 18.72 & 220 & 12.94 \\
\hline$F$ test & $*$ & $*$ & $*$ & $*$ & $*$ & $*$ & $*$ & $*$ \\
\hline LSD 5\% & 0.02 & 0.80 & 26.4 & 0.72 & 0.03 & 1.75 & 33.5 & 3.14 \\
\hline \multicolumn{9}{|c|}{ Microbial biomass } \\
\hline Autoclaved soil & 0.39 & 20.88 & 324 & 16.07 & 0.21 & 16.85 & 84 & 7.06 \\
\hline Fresh soil & 0.43 & 20.25 & 565 & 19.52 & 0.45 & 18.05 & 143 & 7.62 \\
\hline$F$ test & $*$ & $*$ & $*$ & $*$ & $*$ & $*$ & $*$ & $*$ \\
\hline LSD 5\% & 0.04 & 0.22 & 31.3 & 0.75 & - & 0.28 & 18.1 & 0.26 \\
\hline
\end{tabular}

${ }^{*}$ Significant at $P \leq 0.05$, ns: not significant, and SDW: shoot dry weight of rice.

equation. Microbial $\mathrm{N}$ flush was converted to $\mathrm{MBN}$ using a $K_{\mathrm{EN}}$ factor of 0.45 [29].

$$
\begin{aligned}
& \text { Microbial biomass } \mathrm{N} \\
& \begin{array}{l}
=(\mathrm{TN} \text { under fresh soil }-\mathrm{TN} \text { under autoclaved soil }) \\
\quad \times 0.45
\end{array}
\end{aligned}
$$

where $\mathrm{TN}$ under autoclaved soil $=$ Total $\mathrm{N}$ in rice shoot grown in autoclaved soil, and TN under fresh soil = Total $\mathrm{N}$ in rice shoot grown in fresh soil.

The MBN is controlled by two factors: (i) the amount of $\mathrm{N}$ accumulated during growth and (ii) the proportion of plant nitrogen derived from microbial biomass $\left(P_{\text {fix }}\right)$, which can be calculated as follows:

$$
\begin{aligned}
P_{\text {fix }}(\%)= & \text { Amount of microbial N }(\text { mg pot }-1) \\
& \times 100 / \text { TNuptake }(\text { mg pot }-1) .
\end{aligned}
$$

2.4. Statistical Analyses. Data were performed by a oneway analysis of variance (ANOVA) for a design type here, that is, complete randomized block design [30]. These results based on combination analysis of the two years. A Mstatc software program (citation) [31] was used to conduct the analysis of variance. A correlation procedure [32] was used to determine the correlation coefficients between soil ammonium concentration, microbial nitrogen, and $P_{\text {fix }}$ for each treatment. The significance of treatment mean was determined at $P<0.05$ with the LSD test.

\section{Results and Discussion}

3.1. Effect of Microbial Biomass and Nitrogen Sources on Nitrogen Dynamics and Shoot Dry Weight. As shown in Table 2, there was a significant difference between nitrogen sources for $\mathrm{N}$ in soil, $\mathrm{NH}_{4}-\mathrm{N}, \mathrm{N}$ uptake, and SDW under both soils. The highest ammonium content was recorded in organically treated pots with rice straw compost in clay and loamy soils, and the least in urea-treated pots in both soils irrespective of the control. Nitrogen mineralization between inorganic and organic treatments showed significant variation in both soils. Inorganically treated pot amended with urea showed the highest $\mathrm{N}$ uptake and SDW in clay soil followed by sludge and rice-straw-treated pots and least in control. In contrast, organically treated pots amended with rice straw and sludge showed the highest $\mathrm{N}$ uptake and SDW in loamy soil followed by urea-treated pot.

The amount of mineralization $\left(\mathrm{NH}_{4}-\mathrm{N}\right)$ of organic $\mathrm{N}$ was more than that from urea fertilizer [33]. Organic matter with $\mathrm{C} / \mathrm{N}$ ratio as seen in sludge produced a low $\mathrm{NH}_{4}-\mathrm{N}$ compared to straw compost with low $\mathrm{C} / \mathrm{N}$ ratio. This may be attributed to the fact that materials with low $\mathrm{C} / \mathrm{N}$ immobilize more $\mathrm{N}$, and the release of the immobilized $\mathrm{N}$ is retarded [27, 34]. This phenomenon plays a big role in microbial activity especially free-living bacteria. Fresh soil treatment was affected by the total $\mathrm{N}$ in the soil, nitrogen mineralization, $\mathrm{N}$ uptake, and SDW in both soils (Table 2). In the inoculated pots, the organic matter was previously decomposed by general purpose decomposing bacteria before application. It has been shown that if organic matter applied to soil, some of the liberated $\mathrm{NH}_{4}-\mathrm{N}$ is fixed in soil, and then denitrification will be decreased [27]. Although the total $\mathrm{N}$ in the soil was higher under inoculated pots than un-inoculated one, the ammonium in the soil was higher under uninoculated treatment in both soils. Reference [35] reported that in the first stage of plant life, the anaerobic and aerobic bacteria need energy and nutrient especially nitrogen which are obtained from easily decomposable water-soluble organic compounds in soil solution or adsorbed to the soil itself. Later, the microorganisms, soil biomass, are decomposed by 
TABle 3: Total N uptake, bacterial $N$ uptake, and $P_{\text {fix }}$ (combined of two years) in rice cv. Giza 177 as affected by nitrogen sources.

\begin{tabular}{|c|c|c|c|c|c|c|}
\hline \multirow{2}{*}{ Treatments } & \multicolumn{3}{|c|}{ Clay soil } & \multicolumn{3}{|c|}{ Loamy soil } \\
\hline & $\mathrm{TN}$ in shoot $(\%)$ & $\begin{array}{l}\text { bacterial N uptake } \\
\left(\mathrm{mg} \mathrm{pot}^{-1}\right)\end{array}$ & $P_{\text {fix }}(\%)$ & $\mathrm{TN}$ in shoot $(\%)$ & $\begin{array}{l}\text { bacterial N uptake } \\
\left(\mathrm{mg} \mathrm{pot}^{-1}\right)\end{array}$ & $P_{\text {fix }}(\%)$ \\
\hline \multicolumn{7}{|l|}{$\begin{array}{l}\text { Nitrogen } \\
\text { sources }\end{array}$} \\
\hline Zero $\mathrm{N}$ & 1.30 & 23 & 14.7 & 0.87 & 3.3 & 5.5 \\
\hline Urea & 1.86 & 61 & 18.4 & 1.09 & 13.8 & 12.5 \\
\hline Straw & 2.66 & 112 & 20.1 & 1.22 & 27.5 & 17.2 \\
\hline Sludge & 2.91 & 125 & 21.5 & 1.52 & 39.0 & 19.5 \\
\hline$F$ test & $*$ & $*$ & $*$ & $*$ & $*$ & $*$ \\
\hline LSD $5 \%$ & 0.20 & 14.6 & 1.2 & 0.18 & 11.4 & 1.85 \\
\hline
\end{tabular}

* Significant at $P<0.05$, ns: no significant, and $P_{\text {fix }}$ : the proportion of plant $\mathrm{N}$ derived from microbial biomass.

other microbes, and then the nitrogen will be mineralized to ammonium followed by nitrification to nitrate. It has been observed that from the results in this experiment, the marked increase of the total $\mathrm{N}$ in soil under inoculated pot may be attributed not only to high population of microorganism and its activity but also to some of bacteria able to fix the atmospheric nitrogen which add additional nitrogen to the soil [8]. Clay soil had higher level of soil $\mathrm{NH}_{4}$ than the loamy soil. References $[36,37$ ] found that the lower $\mathrm{N}$ uptake associated with light soil is likely to be a function of greater volatilization losses compared to clay soil. These results suggest that there may be subtle differences in $\mathrm{N}$ cycling between both soils. The relatively high $\mathrm{NH}_{4}$ levels in clay suggest that plant available $\mathrm{N}$ may be higher in clay soil than loamy soil. Also, the total $\mathrm{N}$ uptake by rice shoot was lower under urea application than in organic-matteramended pots, although all pots had received equal dose of nitrogen. At low $\mathrm{C} / \mathrm{N}$ ratios as observed with straw manure, ammonia tends to accumulate, and most of them are lost through volatilization process and cause nitrogen loss [38]. Organic materials with low $\mathrm{C} / \mathrm{N}$ are generally broken down more quickly than those materials with high $\mathrm{C} / \mathrm{N}[27,34]$. These results of literatures confirm why sludge-amended pot generated $\mathrm{NH}_{4}$ more than straw compost in both soils. Also, this phenomenon plays a big role in activity of freeliving bacteria under flooding condition. Microorganisms activity associated with coarse soil texture do not grow well compared to clay loam soil [39]. BGA + bacteria treatment produced higher $\mathrm{N}$ uptake and SDW than bacteria treatment. In addition, blue green algae upper the soil service introduce some atmospheric $\mathrm{N}$ to rice culture and protect the ammonia from loss through volatilization [27].

\subsection{Effect of Different Nitrogen Sources on Microbial Biomass} Nitrogen and Its Relationship with Nitrogen Mineralization. Total microbial nitrogen is a natural system of microbial mobilization of atmospheric nitrogen; in addition, the nitrogen decayed from the bacteria itself which can be easily available and utilized by plants mediated by different microorganisms such as free-living bacteria. The nitrogen sources appear to have the most relevance for microbial nitrogen mass in soil [40]. Selection of the type of soil amendment especially under flooding condition played a very important role in enhancing microbial $\mathrm{N}$ inputs as will be explained below. One strategy available for flooded rice condition is to minimize the addition of nitrogen fertilizers [41]. With slow-release-ammonium as shown in sludge amended soil, the soil fertility was compensated by different sources of microbial nitrogen under anaerobic condition, thereby reducing the production cost [21]. Leaching and loss of excess nitrogen derived from applying fertilizers are usually greater with flooded soil. From the data analyzed in this experiment, nitrogen sources and the microbial biomass had much greater effects on the microbial $\mathrm{N}$ uptake and $P_{\text {fix }}$ in both soils under study (Table 3 ). In spite of the differences found among nitrogen sources (Urea, rice straw, and sludge) for the amount of microbial $\mathrm{N}$ absorbed by rice plant, there was no significant difference between rice straw and sludge manures under clay soil compared with loamy soil. On the other hand, there was a difference among nitrogen sources in both clay and loamy soils for $P_{\text {fix }}$, which was the highest under sludge treatment (21.5 and 19.5\%, resp.) followed by rice straw (20.1 and $17.2 \%$, resp.). Increasing microbial $\mathrm{N}$ uptake rates under sludge treatment leads to the possibility of improving nitrogen use efficiency in both soils. These results indicated that organic amendments with high $\mathrm{C}$ content as shown in sludge (Table 1) may increase the $\mathrm{N}$ immobilization by soil microbes, resulting in a lower rate and longer period of $\mathrm{N}$ uptake by plants [28]. Positive correlations were found between $\mathrm{N}$ uptake and both of the microbial $\mathrm{N}$ uptake and $P_{\text {fix }}$ in both clay soil $(R=0.96$ and $R=0.98$, resp. $)$ and loamy soil $(R=0.92$ and $R=$ 0.99 , resp.) as affected by nitrogen sources regardless of the control (Figures 1 and 2). It can be observed from these figures that the $P_{\text {fix }}$ was more correlated with $\mathrm{N}$ uptake than microbial $\mathrm{N}$ uptake in both soils. Free-living microbes in paddy soil grow well without the addition of nitrogen fertilizer or slow $\mathrm{N}$ mineralization [14]. Our results suggested that not only organic phosphorus and carbon contents affect the amount of microbial $\mathrm{N}$ in rice plant but also the amount 


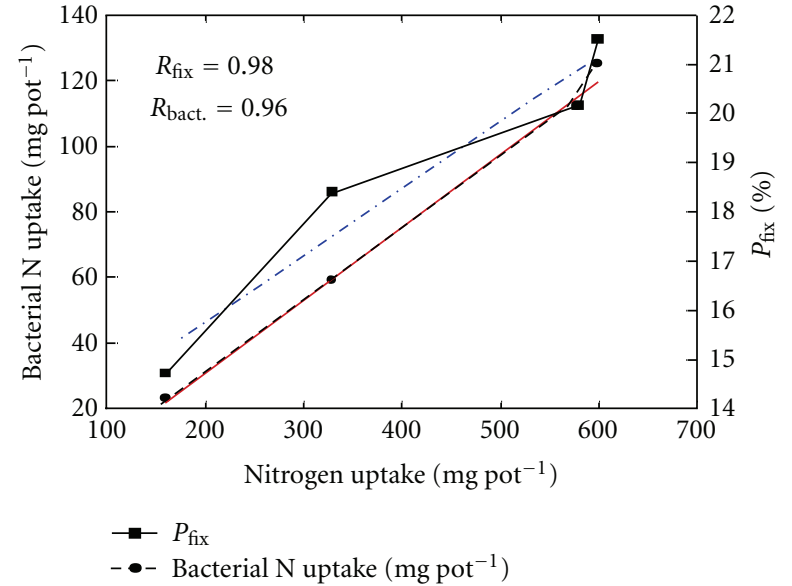

FIGURE 1: Relationship between total $\mathrm{N}$ uptake, bacterial $\mathrm{N}$ uptake and $P_{\text {fix }}$ as affected by nitrogen sources in rice cv. Giza 177 under clay soil.

of ammonium under flooding condition. The relationship between $P_{\text {fix }}$ and $\mathrm{NH}_{4}-\mathrm{N}$ confirmed the reduction in microbial $\mathrm{N}$ uptake under straw treatment as shown in Figures 3 and 4. Optimum level of available nitrogen $\left(\mathrm{NH}_{4}{ }^{+}\right)$in soil has been shown to enhance the capacity of total microbial nitrogen production in the presence of an adequate number of effective free-living bacteria [42]. But the presence of more minerals $\mathrm{N}$ greatly inhibits $\mathrm{N}_{2}$ fixers [43]. It was shown that $\mathrm{NH}_{4}{ }^{+}$was more severely inhibiting than $\mathrm{NO}_{3}{ }^{-}$or $\mathrm{NO}_{2}{ }^{-}$ to free-living and endophytic bacteria in paddy soils [27]. Also, ammonium is well known to inhibit the synthesis of nitrogenase but not its activity. In a paddy soil, growing rice plants with high concentration of $\mathrm{NH}_{4}{ }^{+}-\mathrm{N}$ lowered the microbial $\mathrm{N}$ production, and asimilar result has been reported by [44]. However, application of organic nitrogen sources such as sludge to paddy soil not only stabilizes soil $\mathrm{pH}$ and nutrients availability [8], but also enhances the soil microbial activity due to the organic phosphorus (4800 $\mathrm{mg} \mathrm{Kg}^{-1}$, Table 1) and carbon which is contained in these materials [12]. This could also demonstrate that why the amount of microbial $\mathrm{N}$ absorbed by rice plant was higher under sludge-amended soil compared with straw compost or chemical fertilizer. However, further study is necessary to support this hypothesis.

Many studies have indicated that reducing $\mathrm{NO}_{3}{ }^{-}$leaching is the greatest challenge to improve the efficiency of $\mathrm{N}$ use in soil $[45,46]$. If we can use $\mathrm{MBN}$ as a temporal $\mathrm{N}$ sink during the flooding condition by applying organic amendment as observed by Hirai et al. [47], we should be able to decrease the service $\mathrm{N}$ leaching and improve the efficiency of $\mathrm{N}$ use in the soil [48]. Because the microbial $\mathrm{N}$ uptake by rice plant in the sludge and straw-amended pots were greater than that in the urea-amended pot, organic matter application appeared to improve the efficiency of $\mathrm{N}$ use in the soil compared with chemical fertilizer alone. As we could not observe a clear effect of organic matter application on the dynamic of microbial biomass nitrogen, future studies should focus on the effect of plant residues and organic

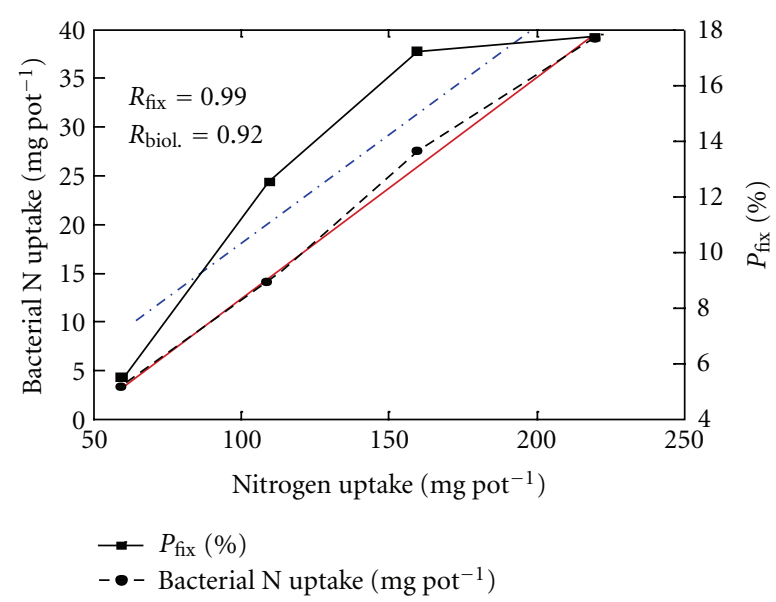

FIGURE 2: Relationship between total $\mathrm{N}$ uptake, bacterial $\mathrm{N}$ uptake, and $P_{\text {fix }}$ as affected by nitrogen sources in rice cv. Giza 177 under silt loam soil.

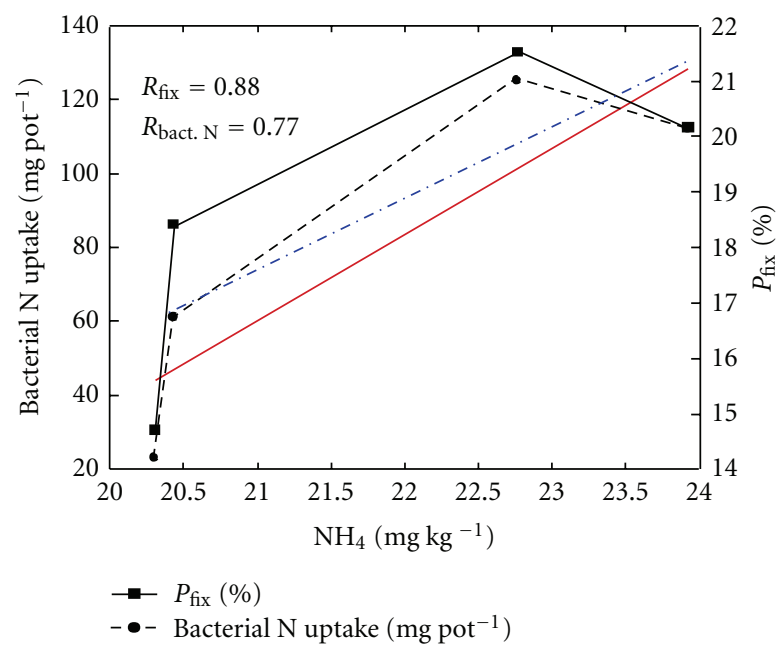

FIGURE 3: Relationship between ammonium, bacterial $\mathrm{N}$ uptake and $P_{\text {fix }}$ as affected by nitrogen sources in rice cv. Giza 177 under clay soil.

matter and/or fertilizer application on temporal of MBN variations in relation to $\mathrm{N}$ loss from flooded soil and plant $\mathrm{N}$ uptake.

\section{Conclusion}

It can be safely said that not all nitrogen sources can serve well the anaerobic free-living bacteria and make balance of soil nitrogen in paddy soil regardless of the type of soil. Consequently, free-living bacteria in sludge-amended soil enhanced the total nitrogen uptake by rice plant in both clay and loamy soils and then increased the dry matter production. Fresh soil amended by sludge increased plant nitrogen consistently. Positive microbial $\mathrm{N}$ uptake by rice plant to the native free-living microbes was enhanced rather than suppressed at high nitrogen mineralization rate. Based 


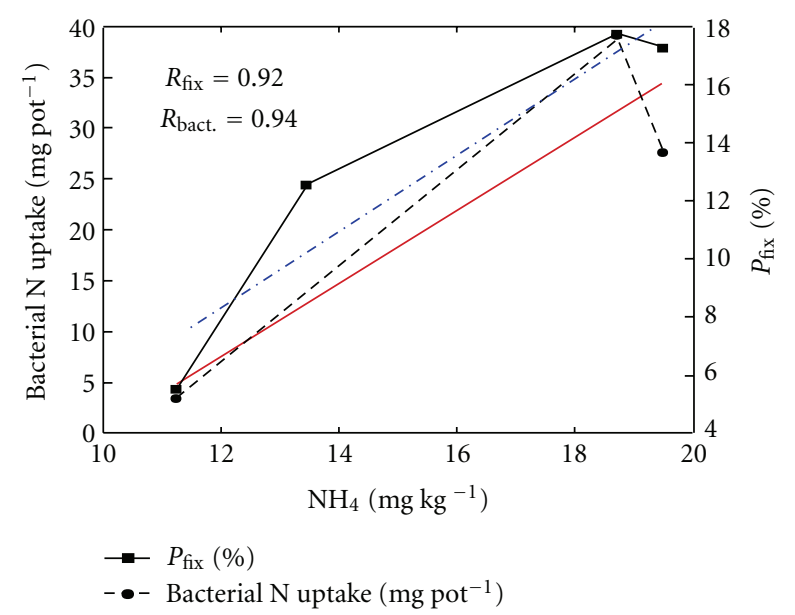

FIgURE 4: Relationship between ammonium, bacterial N uptake, and $P_{\text {fix }}$ as affected by nitrogen sources in rice cv. Giza 177 under silt loam soil.

on the results obtained and on the information available, we suggest ways for exploiting MBN production for sustainable agriculture in paddy field condition.

\section{References}

[1] T. Higa and G. N. Wididana, "Changes in the soil microflora Induced by effective microorganisms," in Proceedings of the 1st International Conference on Kyusei Nature Farming, J. F. Parr, S. B. Hornick, and C. E. Whitman, Eds., pp. 153-162, U.S. Department of Agriculture, 1991.

[2] T. Higa, "Effective microorganisms: a new dimension for nature farming," in Proceedings of the 2nd International Conference on Kyusei Nature Farming, J. F. Parr, S. B. Hornick, and M. E. Simpson, Eds., pp. 20-22, U.S. Department of Agriculture, 1994.

[3] T. Higa, "Effective microorganisms: their role in Kyusei Nature Farming and sustainable agriculture," in Proceedings of the 3rd International Conference on Kyusei Nature Farming, J. F. Parr, S. B. Hornick, and M. E. Simpson, Eds., U.S. Department of Agriculture, 1995.

[4] D. R. Keeney and D. W. Nelson, "Nitrogen-inorganic forms," in Methods of soil Analysis, part 2. Chemical and Microbiological Properties, A. Page, Ed., pp. 643-693, American Society of Agronomy, Inc., Crop Science Society of America, Inc., and Soil Science Society of America, Inc., Madison, Wis, USA, 1982.

[5] A. I. Saralov and T. R. Babanazarov, "Characteristics of the microflora and nitrogen fixation in the takyr soils of the rice fields in the Karakapak ASSR," Microbiology, vol. 51, pp. 682686, 1983.

[6] T. Yoneyama, "N2 fixation by three types of plant-microbe interaction: carbon as the major limiting," in Proceedings of the Plant-Microbe Interaction, pp. 33-44, Chonnam National University, Korea, April 2002.

[7] D. H. Hubbell and K. Gerald, "Biological Nitrogen Fixation; The Importance of Nitrogen," Soil and Water Science Department, Florida Cooperative Extension Service, Institute of Food and Agricultural Sciences, University of Florida, 2003, http://edis.ifas.ufl.edu/.
[8] H. M. El Sharkawi, S. Yamamoto, and T. Honna, "Rice yield and nutrient uptake as affected by cyanobacteria and soil amendments - a pot experiment," Journal of Plant Nutrition and Soil Science, vol. 169, no. 6, pp. 809-815, 2006.

[9] P. A. Roger and J. K. Ladha, "Biological N2 Fixation in wetland rice fields: estimation and contribution to nitrogen balance," Plant and Soil, vol. 141, no. 1-2, pp. 41-55, 1992.

[10] P. Irisarri, S. Gonnet, and J. Monza, "Cyanobacteria in Uruguayan rice fields: diversity, nitrogen fixing ability and tolerance to herbicides and combined nitrogen," Journal of Biotechnology, vol. 91, no. 2-3, pp. 95-103, 2001.

[11] T. W. Bruulsema, P. E. Fixen, and C. S. Snyder, "Fertilizer nutrient recovery in sustainable cropping systems," Better Crops, vol. 88, pp. 15-17, 2004.

[12] S. A. Materechera and A. M. Salagae, "Use of partially decomposed cattle and chicken compost amendment with wood ash in two South Africa arable soils with contrasting texture, effect on nutrient uptake, early growth, and dry matter yield of maize," Communications in Soil Science and Plant Analysis, vol. 33, pp. 179-201, 2002.

[13] D. M. Halsall and A. H. Gibson, "Cellulose decomposition and associated nitrogen fixation by mixed cultures of Cellulomonas gelida and Azospirillum species or Bacillus macerans," Applied and Environmental Microbiology, vol. 50, no. 4, pp. 1021-1026, 1985.

[14] J. K. Ladha, A.T. Padre, D. N. Nayak, M. Garcia, and I. Watanabe, "Nitrogen fixation by single and mixed heterotrophic bacteria in flooded paddy soil amended with hydrogen peroxide treated straw (hemicellulose)," in Proceedings of the 4th International Symposium on Microbial Ecology, pp. 603-608, 1986.

[15] Yadvinder-Singh, Manpreet-Singh, H. S. Sidhu et al., Options for effective utilization of crop residues, Directorate of Research, Punjab Agricultural University, Ludhiana, India, 2010.

[16] J. M. Lynch and S. H. T. Harper, "Straw as a substrate for cooperative nitrogen fixation," Journal of General Microbiology, vol. 129, pp. 251-253, 1983.

[17] M. M. Roper and D. M. Halsall, "Use of products of straw decomposition by $\mathrm{N} 2$-fixing $\left(\mathrm{C}_{2} \mathrm{H}_{2}\right.$-reducing) populations of bacteria in three soils from wheat-growing areas," Australian Journal of Agricultural Research, vol. 37, pp. 1-9, 1986.

[18] S. Coq, B. G. Barthès, R. Oliver, B. Rabary, and E. Blanchart, "Earthworm activity affects soil aggregation and organic matter dynamics according to the quality and localization of crop residues-an experimental study (Madagascar)," Soil Biology and Biochemistry, vol. 39, no. 8, pp. 2119-2128, 2007.

[19] H. R McKenzie, "Soil pH and plant nutrition. Agriculture food and rural development," AGRI-FACTS, May, Agdex 531-4: 12, 2003.

[20] M. M. Roper and J. K. Ladha, "Biological N2 fixation by heterotrophic and phototrophic bacteria in association with straw," Plant and Soil, vol. 174, no. 1-2, pp. 211-224, 1995.

[21] M. B. Peoples, D. F. Herridge, and J. K. Ladha, "Biological nitrogen fixation: an efficient source of nitrogen for sustainable agricultural production?" Plant and Soil, vol. 174, no. 1-2, pp. 3-28, 1995.

[22] Soil Survey Staff, "Soil survey laboratory methods manual," Soil Survey Investigations Report 42, USDA-NRCS, Washington, DC, USA, 1996.

[23] E. D. Rhine, G. K. Sims, R. L. Mulvaney, and E. J. Pratt, "Improving the Berthelot reaction for determining ammonium in soil extracts and water," Soil Science Society of America Journal, vol. 62, no. 2, pp. 473-480, 1998. 
[24] R. R. Jimenez and J. K. Ladha, "Automated elemental analysis: a rapid and reliable but expensive measurement of total carbon and nitrogen in plant and soil samples," Communications in Soil Science \& Plant Analysis, vol. 24, no. 15-16, pp. 18971924, 1993.

[25] D. F. Bezdicek, D. W. Evans, B. Abede, and R. E. Witters, "Evaluation of peat and granular inoculums (Rhizobium japonicum) for soybean yield and nitrogen fixation under irrigation," Agronomy Journal, vol. 70, pp. 865-868, 1978.

[26] A. M. McNeill, C. J. Pilbeam, H. C. Harris, and R. S. Swift, "Seasonal variation in the suitability of different methods for estimating biological nitrogen fixation by grain legumes under rainfed conditions," Australian Journal of Agriculture Research, vol. 47, no. 7, pp. 1061-1073, 1996.

[27] K. Kyuma, "Fertility considerations for paddy soil (I) general nutrient balance and nitrogen," in Paddy Soil Science, p. 132, Kyoto University Press, 2004.

[28] S. Sugihara, S. Funakawa, M. Kilasara, and T. Kosaki, "Dynamics of microbial biomass nitrogen in relation to plant nitrogen uptake during the crop growth period in a dry tropical cropland in Tanzania," Soil Science and Plant Nutrition, vol. 56, no. 1, pp. 105-114, 2010.

[29] P. C. Brookes, A. Landman, G. Pruden, and D. S. Jenkinson, "Chloroform fumigation and the release of soil nitrogen: a rapid direct extraction method to measure microbial biomass nitrogen in soil," Soil Biology and Biochemistry, vol. 17, no. 6, pp. 837-842, 1985.

[30] G. W. Snedecor and W. G. Cochran, Statistical Methods, Iowa State University Press, Ames, Iowa, USA, 7th edition, 1980.

[31] MSTATC, A Microcomputer Program for the Design, Management, and Analysis of Agronomic Research Experiments, Michigan State University, East Lansing, Mich, USA, 1990.

[32] SAS Institute, SAS User's Guide: Statistics, SAS Institute, Cary, NC, USA, 4th edition, 1990.

[33] K. Hasegawa, "Studies on the dynamics of nitrogen in paddy soils and its environmental impact," Special Bulletin of the Shiga Agricultural Experiment Station, vol. 17, pp. 1-164, 1992 (Japanese).

[34] Z. Ahmad, H. Kai, and T. Harada, "Factors affecting immobilization and release of nitrogen in soil and chemical characteristics of the nitrogen newly immobilized II. Effect of carbon sources on immobilization and release of nitrogen in soil," Soil Science and Plant Nutrition, vol. 15, no. 6, pp. 252-258, 1969.

[35] S. T. Jakobsen, "Aerobic decomposition of organic wastes 2. Value of compost as a fertilizer," Resources, Conservation and Recycling, vol. 13, no. 1, pp. 57-71, 1995.

[36] D. S. Schimel and W. J. Parton, "Microclimatic controls of nitrogen mineralization and nitrification in shortgrass steppe soils," Plant and Soil, vol. 93, no. 3, pp. 347-357, 1986.

[37] J. A. Delgado, A. R. Mosier, D. W. Valentine, D. S. Schimel, and W. J. Parton, "Long term $15 \mathrm{~N}$ studies in a catena of the shortgrass steppe," Biogeochemistry, vol. 32, no. 1, pp. 41-52, 1996.

[38] K. Fog, "The effect of added nitrogen on the rate of decomposition of organic matter," Biological Reviews, vol. 63, no. 3, pp. 433-462, 1988.

[39] Soil Quality Information Sheet, "Physical and Biological Soil Crusts," USDA, Natural Resources Conservation Service, 2001, http://soils.usda.gov/sqi/.

[40] M. Al-Kaisi Mahdi, L. Kruse Marc, and E. Sawyer John, "Effect of nitrogen fertilizer application on growing season soil carbon dioxide emission in a corn-soybean rotation," Journal of Environmental Quality, vol. 37, pp. 325-332, 2008.

[41] H. Ke, L. HuaXing, L. WeiSheng, L. YuanJin, and W. LiBin, "Effect of microbial organic fertilizer application on soil microbial activity," Chinese Journal of EcoAgriculture, vol. 18, no. 2, pp. 303-306, 2010.

[42] H. Hogh-Jensen and J. K. Schjoerring, "Measurement of biological dinitrogen fixation in grassland: comparison of the enriched $15 \mathrm{~N}$ dilution and the natural $15 \mathrm{~N}$ abundance methods at different nitrogen application rates and defoliation frequencies," Plant and Soil, vol. 166, no. 2, pp. 153-163, 1994.

[43] M. M. Roper and N. A. Smith, "Straw decomposition and nitrogenase activity $\left(\mathrm{C}_{2} \mathrm{H}_{2}\right.$ reduction) by free-living microorganisms from soil: effects of $\mathrm{pH}$ and clay content," Soil Biology and Biochemistry, vol. 23, no. 3, pp. 275-283, 1991.

[44] T. Yoshida, H. Kai, and T. Harada, "Studies on the build-up of readily decomposable organic matter in soil, III. Carbon minerakization and build-up of readily decomposable organic matter as affected by quality and quantity of applies organic residues," Science Bulletin of the Faculty of Agriculture Kyushu University, vol. 28, pp. 37-48, 1973.

[45] R. Chikowo, P. Mapfumo, P. A. Leffelaar, and K. E. Giller, "Integrating legumes to improve N cycling on smallholder farms in sub-humid Zimbabwe: resource quality, biophysical and environmental limitations," Nutrient Cycling in Agroecosystems, vol. 76, no. 2-3, pp. 219-231, 2006.

[46] A. E. Hartemink, R. J. Buresh, P. M. Van Bodegom, A. R. Braun, B. Jama, and B. H. Janssen, "Inorganic nitrogen dynamics in fallows and maize on an Oxisol and Alfisol in the highlands of Kenya," Geoderma, vol. 98, no. 1-2, pp. 11-33, 2000.

[47] Y. Hirai, Y. Kodama, S. I. Moriwaki et al., "Heterozygous individuals bearing a founder mutation in the XPA DNA repair gene comprise nearly $1 \%$ of the Japanese population," Mutation Research, vol. 601, no. 1-2, pp. 171-178, 2006.

[48] F. Mtambanengwe and P. Mapfumo, "Effects of organic resource quality on soil profile $\mathrm{N}$ dynamics and maize yields on sandy soils in Zimbabwe," Plant and Soil, vol. 281, no. 1-2, pp. 173-191, 2006. 

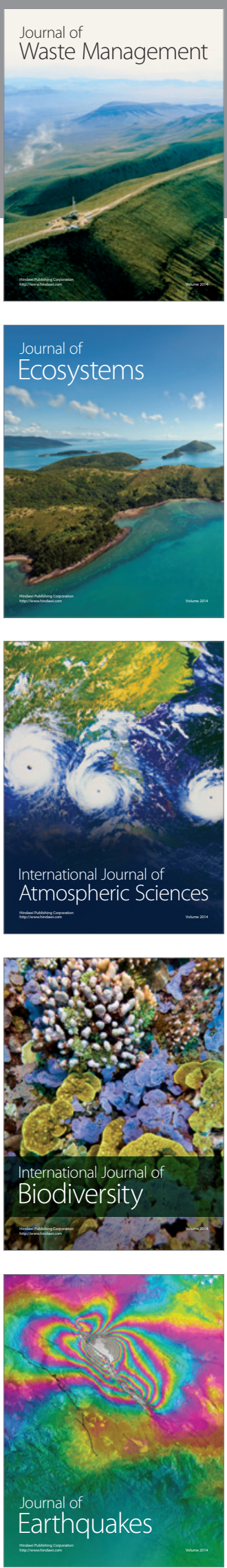
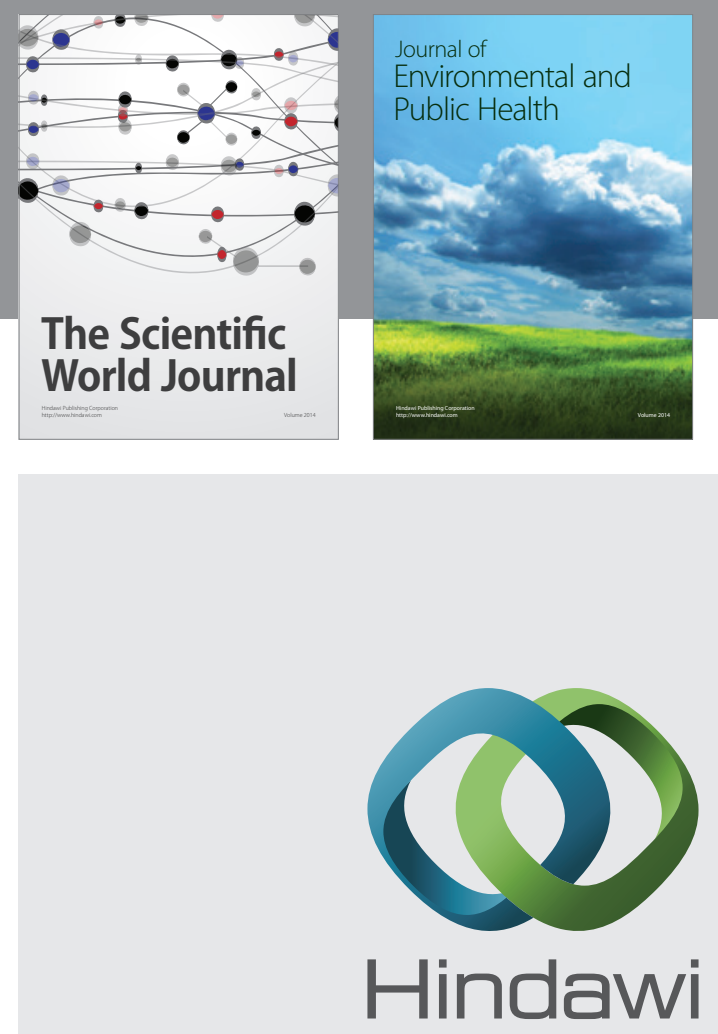

Submit your manuscripts at

http://www.hindawi.com
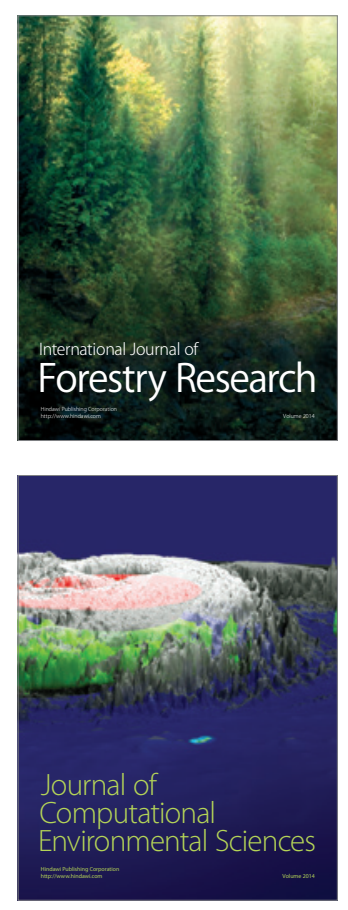
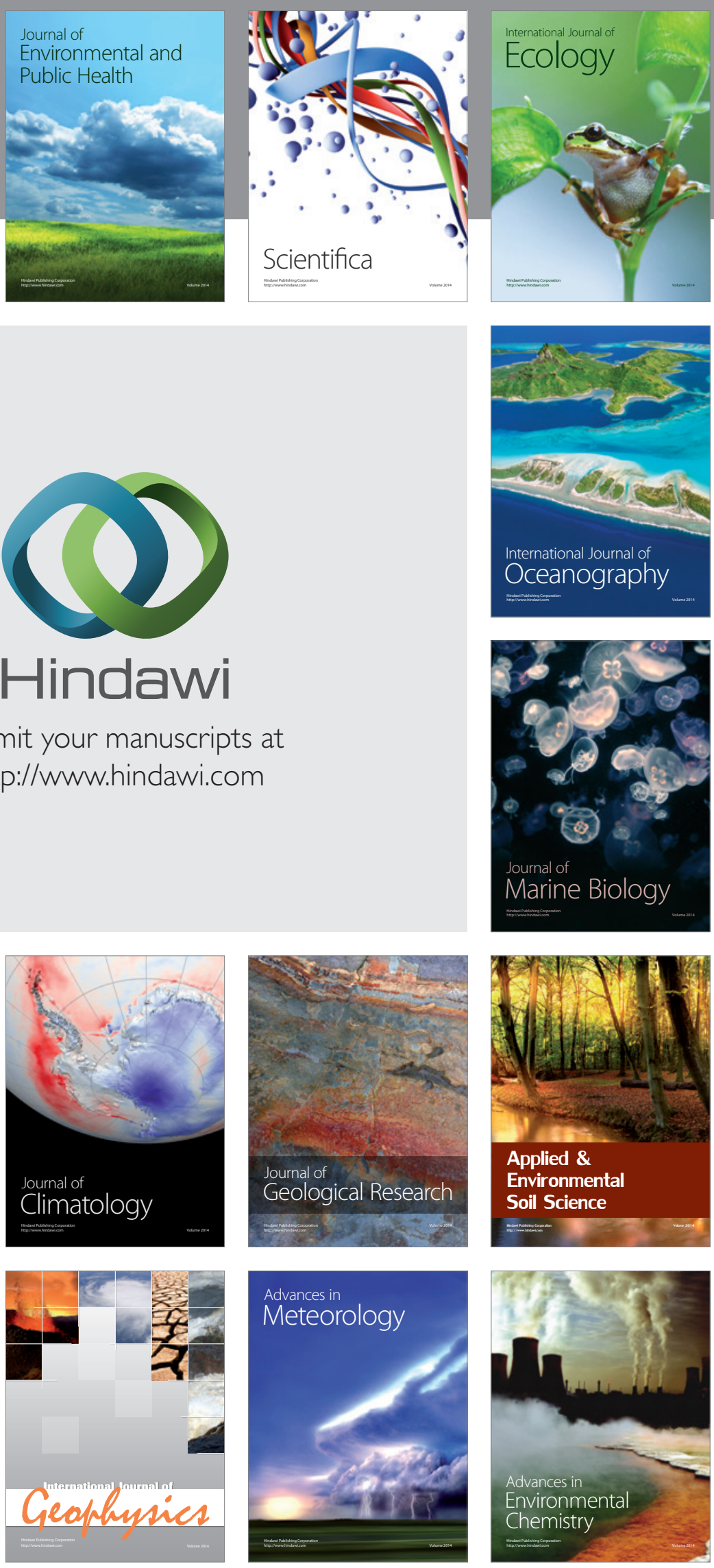